DOI: http://dx.doi.org/10.33846/hn40403

http://heanoti.com/index.php/hn

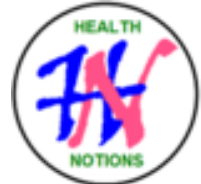

RESEARCH ARTICLE

URL of this article: http://heanoti.com/index.php/hn/article/view/hn40403

\title{
Variation of Molasses Dose in Making Solid Organic Fertilizer with Fresh Cow Dung
}

\author{
Karno $^{1(\mathrm{CA})}$, Sunaryo ${ }^{2}$, Frida Hendrarinata ${ }^{3}$ \\ ${ }^{1(\mathrm{CA})}$ Environmental Health Program of Magetan, Poltekkes Kemenkes Surabaya, Indonesia; \\ karno.psklae@gmail.com (Corresponding Author) \\ ${ }^{2}$ Environmental Health Program of Magetan, Poltekkes Kemenkes Surabaya, Indonesia:naryo82@yahoo.co.id \\ ${ }^{3}$ Environmental Health Program of Magetan, Poltekkes Kemenkes Surabaya, \\ Indonesia;fridahendrarinata7710@gmail.com
}

\begin{abstract}
Introduction: Livestock population in Magetan, East Java Province, Indonesia is quite high, which is 58.671 animals This can be become a potency for development of organic fertilizer with fresh cow dung as the raw material. For producing biogas from cow dung, it needs to be conducted appropriate technological innovation, thus, it can be used and can reduce environmental pollution. Methods: The research's method was eksperimental research. Purpose: Identifying the measuring the levels of: macronutrient of organic fertilizer in this research: N, P, K, and C-organic. Analyzing exact fermentation time in making organic fertilizer from variation in the comparison of molasses. Result: The organic levels of N, P, K and C showed that it qualified the standard of Regulation of the Ministry of Agriculture Number 70/ PERMENTAN / SR. 140 / 102011. Based on the research result, it was obtained that the fastest of fermentation time was in variation 4 with the comparison of addition of molasses dose in $200 \mathrm{ml}$ and EM4 in $50 \mathrm{ml}$.
\end{abstract}

Keywords: molasses; organic fertilizer; fresh cow dung

\section{INTRODUCTION}

\section{Background}

The applied EM4 had a good influence on the physical properties of the soil. ${ }^{(1)}$.The content of biogas is carbon dioxide $\left(\mathrm{CO}_{2}\right)$ and methane $\left(\mathrm{CH}_{4}\right)$. The small amount of them contains hydrogen sulfide $\left(\mathrm{H}_{2} \mathrm{~S}\right)$ and ammonia $\left(\mathrm{NH}_{3}\right)$ and the smallest content of them is such as hydrogen and $\left(\mathrm{H}_{2}\right)$. Energy that is contained from methane $\left(\mathrm{CH}_{4}\right)$ concentration is the higher the methane, the bigger the energy (calorific value) in biogas, and vice versa, the smaller the methane, the smaller the calorific value. Thus, in order to be able to add the quality of biogas, it can be conducted by omitting hydrogen sulfur, water content, and carbon dioxide $\left(\mathrm{CO}_{2}\right)^{(2)}$.

As we know that biogas is gas mixture that is produced by methanogenic bacteria which is occurred on materials that can be decomposed naturally. In anaerobic condition in its process, biogas must be through three stages, which are hydrolysis, acidification and methanogenesis ${ }^{(2)}$. Biogas is produced by the help from methanogenic bacteria. This bacterium naturally is in the waste that contains organic material, such as livestock waste and organic waste. Commonly, biogas is produced by using equipment, which is biogas reactor (digester) that is designed so that it will be anaerobic. Thus, decomposition process by microorganism can be optimal.

Livestock population in Magetan is quite high, which is 58.671 animals . This can be become a potency for development of organic fertilizer with fresh cow dung as the raw material.In order to produce biogas from cattle dung, it needs to be conducted innovation of appropriate technology, hence, it can be used and can reduce environmental pollution. Limitation of Research Problem This research was limited on the addition of molasses dose with various variation of dose in cow dung. Statement of Problem Based on the background of this research, it is found a problem that: "How to determine the exact molasses dose in hastening the process of making organic fertilizer with fresh cow dung as the raw material. 
Purpose

Identifying measuring the content of: macronutrient of organic fertilizer in this research: $\mathrm{N}, \mathrm{P}, \mathrm{K}$, and $\mathrm{C}$ organic. Analyzing exact fermentation time in making organic fertilizer from variation in the comparison of molasses.

\section{METHODS}

Methods: The research's method was eksperimental research. research location in the D.III Laboratory Environmental Health, Magetan Campus, from March to September 2017. Organic fertilizer nutrient elements are macro nutrients that must be present in organic fertilizers as required and in this study are elements: N, P, K and C-Organic. Tools and materials used include: Scales, Plastic tubs of at least $10 \mathrm{~kg}$, Measuring cup size of 250 ml, Dippe, Plastic Bag (Crackle), Fresh cow dung, Fermentor (EM4), Molasses, Sack, Stir bar. The stages of research or operational research are as follows:

1). Fresh cow dung is collected in 5 bags or plastic bag containers with a minimum weight of $5 \mathrm{~kg}$

1). Prepare 5 pieces of black plastic tub with a minimum capacity of $10 \mathrm{~kg}$

2). Considering the research material (fresh cow dung) as much as $5 \mathrm{~kg}$, as much as 5 times (for 5 tubs).

3). Effective administration of microorganisms (EM-4) with varying doses in comparison of the percentages with fresh cow dung under study, namely:

a). 0 (zero): meaning without the administration of fermentor bacteria (only fresh cow dung and molasses as much as $100 \mathrm{ml})$.

b). 25: meaning $25 \mathrm{ml} \mathrm{EM-4,} 5 \mathrm{~kg}$ cow dung, Molasses $100 \mathrm{Ml}$.

c). 50: means $50 \mathrm{ml} \mathrm{EM-4,} 5 \mathrm{~kg}$ cow dung, Molasses $100 \mathrm{Ml}$.

d). 75: means $75 \mathrm{ml}$ EM-4, $5 \mathrm{~kg}$ cow dung, $100 \mathrm{Ml}$ Molasses.

e). 100: means $100 \mathrm{ml}$ EM-4, $5 \mathrm{~kg}$ cow dung, Molasses $100 \mathrm{Ml}$.

This study using a one group post test design research design, where researchers conducted research with treatment for: 0 days, 7 days, 14 days, and 21 days by observing: texture, $\mathrm{pH}$, temperature, color, aroma and mold growth and measuring parameters Nitrogen $(\mathrm{N})$, Phospor $(\mathrm{P})$, Potassium $(\mathrm{K})$ and Carbon $(\mathrm{C})$ for the $21 \mathrm{st}$ day compared to macro nutrients of organic fertilizer namely Nitrogen, Phosphorus, Potassium and Carbon (N, $\mathrm{P}, \mathrm{K}$ and $\mathrm{C}$ ) were required. Descriptive analysis was using data from the results of laboratory examinations in the Faculty of Agriculture, Sebelas Maret University, Surakarta, on macro nutrients in organic fertilizers, including $\mathrm{N}, \mathrm{P}, \mathrm{K}$ and $\mathrm{C}$, which was fermented for 21 days. Data from the results of laboratory examinations were then processed manually and presented in tabular form.

\section{RESULTS}

Table 1. Analysis result of organic fertilizer

\begin{tabular}{|c|c|c|c|c|c|c|}
\hline \multirow{2}{*}{$\begin{array}{c}\text { Code } \\
\text { (total of molasses) }\end{array}$} & $\begin{array}{c}\text { C.Org } \\
(\%)\end{array}$ & $\begin{array}{l}\mathrm{BO} \\
(\%)\end{array}$ & $\begin{array}{l}\mathrm{N} \\
(\%)\end{array}$ & $\begin{array}{l}\mathrm{P}_{2} \mathrm{O}_{5} \\
(\%)\end{array}$ & $\begin{array}{l}\mathrm{K}_{2} \mathrm{O} \\
(\%)\end{array}$ & $\mathrm{C} / \mathrm{N}$ \\
\hline & \multicolumn{2}{|c|}{ Walkley \& Black } & Kjetdhal & \multicolumn{2}{|c|}{$\begin{array}{c}\text { Destruction of } \mathrm{HNO} 3 \& \\
\mathrm{HClO}_{4}\end{array}$} & Calculation \\
\hline Control & 29.47 & 50.82 & 1.09 & 1.03 & 1.07 & 27.04 \\
\hline $\begin{array}{l}\text { Variation } 1 \\
(50 \mathrm{ml})\end{array}$ & 26.45 & 45.60 & 1.18 & 1.06 & 1.05 & 22.42 \\
\hline $\begin{array}{c}\text { Variation } 2 \\
(100 \mathrm{ml})\end{array}$ & 27.50 & 47.41 & 1.18 & 1.50 & 1.36 & 23.31 \\
\hline $\begin{array}{c}\text { Variation } 3 \\
(150 \mathrm{ml})\end{array}$ & 27.11 & 46.73 & 1.27 & 1.22 & 1.36 & 21.35 \\
\hline $\begin{array}{l}\text { Variation } 4 \\
(200 \mathrm{ml})\end{array}$ & 25.66 & 44.24 & 1.58 & 1.25 & 1.46 & 20.53 \\
\hline
\end{tabular}


Table 2. Macronutrient of analysis result from chemistry and soil fertility laboratory with quality standard

\begin{tabular}{cccccc}
\hline $\begin{array}{c}\text { Code } \\
\text { (total of } \\
\text { molasses) }\end{array}$ & \multicolumn{3}{c}{$\begin{array}{c}\text { Macronutrient } \\
\left(\mathrm{N}+\mathrm{P}_{2} \mathrm{O}_{5}+\mathrm{K}_{2} \mathrm{O}\right)\end{array}$} & Total & Quality standard \\
\cline { 2 - 4 } & $\begin{array}{c}\mathrm{N} \\
(\%)\end{array}$ & $\begin{array}{c}\mathrm{P}_{2} \mathrm{O}_{5} \\
(\%)\end{array}$ & $\begin{array}{c}\mathrm{K}_{2} \mathrm{O} \\
(\%)\end{array}$ & & \\
\hline Control & 1.09 & 1.03 & 1.07 & 3.19 & Min 4 \\
$\begin{array}{c}\text { Variation } 1 \\
(50 \mathrm{ml})\end{array}$ & 1.18 & 1.06 & 1.05 & 2.44 & Min 4 \\
$\begin{array}{c}\text { Variation } 2 \\
(100 \mathrm{ml})\end{array}$ & 1.18 & 1.50 & 1.36 & 4.04 & Min 4 \\
$\begin{array}{c}\text { Variation } 3 \\
(150 \mathrm{ml})\end{array}$ & 1.27 & 1.22 & 1.36 & 3.85 & Min 4 \\
$\begin{array}{c}\text { Variation } 4 \\
(200 \mathrm{ml})\end{array}$ & 1.58 & 1.25 & 1.46 & 4.29 & Min 4 \\
\hline
\end{tabular}

Table 3. Analysis of macronutrient of C-organic from chemistry and soil fertility laboratory with quality standard

\begin{tabular}{ccc}
\hline $\begin{array}{c}\text { Code } \\
\text { (total of molasses) }\end{array}$ & $\begin{array}{c}\text { C.Org } \\
(\%)\end{array}$ & Quality standard \\
\hline Control & 29.47 & Min 15 \\
Variation 1 $(50 \mathrm{ml})$ & 26.45 & Min 15 \\
Variation 2 $(100 \mathrm{ml})$ & 27.50 & Min 15 \\
Variation 3 $(150 \mathrm{ml})$ & 27.11 & Min 15 \\
Variation $4(200 \mathrm{ml})$ & 25.66 & Min 15 \\
\hline
\end{tabular}

Table 6 C/N Ratio of analysis result from chemistry and soil fertility laboratory with quality standard

\begin{tabular}{ccc}
\hline $\begin{array}{c}\text { Code } \\
\text { (total of molasses) }\end{array}$ & C/N & Quality standard \\
Control & 27.04 & $15-25$ \\
Variation 1 $(50 \mathrm{ml})$ & 22.42 & $15-25$ \\
Variation 2 $(100 \mathrm{ml})$ & 23.31 & $15-25$ \\
Variation 3 $(150 \mathrm{ml})$ & 21.35 & $15-25$ \\
Variation 4 $(200 \mathrm{ml})$ & 20.53 & $15-25$ \\
\hline
\end{tabular}




\section{DISCUSSION}

Standard of this research result was appropriate with the article 44 of Regulation of the Minister of Research, Technology, and Higher Education (Permenristek Dikti) Number 44 in 2015, which stated that material from research result was directed in order to develop science and technology and also to improve the people's welfare and nation's competitiveness ${ }^{(3)}$ Making liquid organic fertilizer especially from household organic waste by adding bioactivators EM4 (Effective Microorganisms) aims to determine the effect of manufacturing time on the content of $\mathrm{N}, \mathrm{P}, \mathrm{K}$, and $\mathrm{C}$ in liquid organic fertilizer, and determine the effect of EM4 bioactivators on the content of $\mathrm{N}, \mathrm{P}, \mathrm{K}$, and $\mathrm{C}$ in liquid organic fertilizer ${ }^{(4)}$

Livestock manure is used as manure because of its nutrient content such as nitrogen $(\mathrm{N})$, phosphorus $(\mathrm{P})$, and potassium $(\mathrm{K})$ needed by plants and soil fertility and micro nutrients including calcium, magnesium, sulfur, sodium, iron, and copper ${ }^{(5)}$

Then, it resulted solid organic fertilizer which had qualified as what it was stated in Regulation of Ministry of Agriculture Number 70 in $2011^{(6)}$ This could be proven from the analysis result of Chemistry and Soil Fertility laboratory in University of Sebelas Maret Surakarta, which stated that sample of research result that was examined contained all of macronutrient (N,P, and $\mathrm{K}$ ) in complete solid organic fertilizer although it was in small amount. In minimum technical requirement of solid organic fertilizer was not explained for each element of macronutrient in solid organic fertilizer in detail. However, it was enough by determining the cumulative total from calculation of macronutrient $\left(\mathrm{N}, \mathrm{P}_{2} \mathrm{O}_{5}\right.$, and $\left.\mathrm{K}_{2} \mathrm{O}\right)$ with minimum requirement of $4 \%$. The existence of this solid organic fertilizer with fresh cow dung as the raw material was as a source of plant nutrition and it also could be used as soil fertility because the content of this organic fertilizer could repair physical, chemical and biological soil component. This was due to broken soil as the impact of over using the synthetic chemical fertilizers continuously which generally only contained a single nutrient.

Producing solid organic fertilizer with fresh cow dung as the raw material had produced solid organic fertilizer based on minimum technical requirement of solid organic fertilizer that had been determined in Regulation of Ministry of Agriculture Number 70 in $2011^{(6)}$ This could be proven based on final result of this research through examining the quality product of solid organic fertilizer which included the content of macronutrient $(\mathrm{N}, \mathrm{P}, \mathrm{K})$, including the element of organic carbon $(\mathrm{C}$-organic) and ratio between the element of carbon and nitrogen or $\mathrm{C} / \mathrm{Ratio}$. This could be explained by analysis result of laboratory and the determination of parameter from the objective of the research which involved the content of the element, $\mathrm{C}$-organic, and $\mathrm{C} / \mathrm{N}$ ratio. All of the parameters in this research had been fulfilled based on laboratory analysis. One of the most important aspects oftotal nutrient balance is the ratio of organic carbon to nitrogen $(\mathrm{C} / \mathrm{N})$. $\mathrm{C} / \mathrm{N}$ ratio of organic matter is the ratio between the amount of elemental carbon content (C) to the amount of nitrogen element present in an organic material. Microorganisms need carbon and nitrogen for their living activities. If the $\mathrm{C} / \mathrm{N}$ ratio is high, the biological activity of microorganisms will be reduced, it takes several cycles of microorganisms to degrade compost so that it takes a long time for composting and results in lower quality, if the $\mathrm{C} / \mathrm{N}$ ratio is too low the excess nitrogen that is not used by microorganisms cannot be assimilated and will be lost through volatility as ammonia or denitrified ${ }^{(7)}$

According to the result of laboratory analysis for the parameter of macronutrient which was presented in table 4, it was seen that all of replica results contained macronutrient although there was a difference in total. Furthermore, it was occurred variation of total from the content of macronutrient along with there was variation in giving molasses dose in every replication. In replication of variation 2 (by giving molasses dose in $100 \mathrm{ML}$ ), showed that there was a cumulation of total in macronutrient that qualified in which the requirement was minimum in $4 \%$ and the research result was in $4.04 \%$. Meanwhile, in replication of variation 4 (by givinng molasses dose in $200 \mathrm{ML}$ ), also showed that there was a cumulation of total in macronutrient that qualified in which the requirement was minimum in $4 \%$, whether in research result, it was in $4.29 \%$.

Based on the research result with variation of dose in giving molasses (by the total of giving similar EM4 to all replications) showed that the most optimal in the effectiveness of giving molasses dose for fermentation process in making solid organic fertilizer with fresh cow dung as the raw material were in second variation (100 $\mathrm{ml}$ of molasses) and fourth variation with molasses dose in $200 \mathrm{ml}$.

Based on the result of laboratory analysis for the parameter of Organic Carbon (C-organic) nutrient that was presented in table 4 was seen that all of replication results (5 Replications) contained C-Organic nutrient with the total that qualified the minimum technical requirement of solid organic fertilizer (minimum in $15 \%$ ) and all of variations in result of laboratory analysis were above $25 \%$ and the highest control was in $29.47 \%$ in which it was replication with no addition of molasses. According to the data, it could be explained that in making organic fertilizer with fresh cow dung as the raw material from aspect of C-organic parameter in its replication was sufficient by adding EM-4 in $50 \mathrm{ml}$ during fermentation process and the result had qualified the quality standard of C-Organic. It meant that in fresh cow dung although it contained microorganism for hastening the process in making solid organic fertilizer was needed microorganism addition that was EM-4. 
Furthermore, anaerobe process had many advantages if it was compared with aerobe process, such as it did not need energy for aeration, it was only a little that was produced by sludge, organic content which was pollutant almost all of them were converted to be biogas (methane gas) that had quite high calorific value. The weakness of degradation process was a growth of methane bacteria that had very low ability and for its doubling, it needed two until five days. Therefore, it needed reactor that had quite big volume. ${ }^{(8)}$

Nevertheless, without any addition of molasses dose, in table IV.5 showed that only giving EM-4 was through giving and improving the variation of molasses dose which impacted on the decrease of C-Organic percentage although it was still in the minimum quality standard. Hence, without any addition of variation in molasses dose, the process in making $\mathrm{C}$-organic was still going on. result of laboratory test $\mathrm{N}, \mathrm{P}, \mathrm{K} \mathrm{C} / \mathrm{N}$ ratio with the duration of the fermentation process varied between 14 and 21 days ${ }^{(9)}$

According to the result of laboratory analysis for parameter of $\mathrm{C} / \mathrm{N}$ ratio that was presented in table 6 was seen that all of the result of variation in molasses dose (either with or without any addition of variation in molasses dose) still resulted $\mathrm{C} / \mathrm{N}$ ratio that qualified the quality standard, which was $15-25^{(10)}$. It meant that $\mathrm{C} / \mathrm{N}$ ratio from the result of fermentation of fresh cow dung as the raw material for solid organic fertilizer was not depended on whether there was or not the molasses. the addition of EM4 can affect the parameters tested. The addition of EM4 increases the organic $\mathrm{C}$, phosphorus and potassium content ${ }^{(11)}$. Based on the result of laboratory analysis for parameter of $\mathrm{C} / \mathrm{N}$ ratio that was presented in table IV.6, it was seen that result of variation-1 (without any molasses) showed the highest $\mathrm{C} / \mathrm{N}$ ratio, which was 27,04 (control) and the lowest one was 20,53 (the highest variation of molasses dose). Along with the addition of molasses dose, it gave an impact of up and down the $\mathrm{C} / \mathrm{N}$ ratio. The addition of Molasses dose gave an impact on the decrease of $\mathrm{C} / \mathrm{N}$ ratio although it was still in quality standard that was qualified.Write discussion here. This section can be separated into some sub sections.

\section{CONCLUSION}

Result of measuring the organic content of N, P, K and C in 3 weeks showed that it qualified the standard of Regulation of the Ministry of Agriculture (Permentan) Number 70/PERMENTAN/SR.140/102011.Based on the research result, it was obtained that the fastest of fermentation time was in variation 4 with the comparison of addition of molasses dose in $200 \mathrm{ml}$ and EM4 in $50 \mathrm{ml}$.

\section{REFERENCES}

1. Harahap IV. Difference Test between Mixed Cow Manure and Several Agricultural Waste Products against Produced Biogas. Faculty of Agriculture, Universitas Sumatera Utara. 2007;3(4):235-240.

2. Pambudi AN. The use of Biogas as Alternative Energy. Yogyakarta: Department of Mechanical and Industrial Engineering, Faculty of Engineering, Universitas Gajah Mada; 2010.

3. Kemenristek Dikti RI. Regulation of Indonesian Ministry of Research, Technology, and Higher Education Number 13 in Regarding Strategic Plan of Ministry of Research, Technology, and Higher Education in 2015-2019. Jakarta: Ministry of Research, Technology, and Higher Education of The Republic of Indonesia; 2015.

4. Nur T, Noor AR, Elma M. Making of Organic Liquid Fertilizer From Household Organic Waste With The Addition of EM4 Bioactivators (Effective Microorganisms). Conversion. 2016;5(2):5-12.

5. Dwicaksono MRB, Suharto B, Susanawati LD. Effect of Addition of Effective Microorganisms on Fisheries Industry Liquid Waste on the Quality of Organic Liquid Fertilizers. J Sumberd Alam Lingkung. 2014:1(1):7-11.

6. Kementan RI. Regulation of Minister of Agriculture in Republic of Indonesia Number: 70/PERMENTAN/SR.140/10/2011 regarding Organic Fertilizer, Biofertilizer and soil enhancers. Jakarta: Ministry of Agriculture of The Republic of Indonesia; 2011.

7. Trivana L, Pradhana AY, Manambangtua AP. Optimization of Composting Time for Manure from Goat Manure and Coconut Fiber Dust with EM4 Biactivator. J Science and Technology Environment. 2017;9(1):16-24.

8. Mahajoeno E, Lay WB, Sutjahjo HS, Siswanto. Potency of Liquid Waste from Palm Oil Factory for Producing Biogas. Biodiversity. 2008;9:48-52.

9. Suyanto B, Sigit P. Simple Machine for Making Organic Fertilizers in Schools. Health Notions. 2017;1(3): 243-50.

10. Widarti BN, Wardhin WK, Sarwono E. Effect of C / N Ratio of Raw Materials on Making Compost from Cabbage and Banana Skins (Pengaruh Rasio C/N Bahan Baku pada Pembuatan Kompos dari Kubis dan Kulit Pisang). J Integr Proses. 2015;5(2):75-80. 
11. Fitria EL, Dwi Yamika WS, Santosa M. Effect of Biourin, EM4 and Fertilizers on Growth and Yielding of Shallots (Allium ascalonicum L.) Under Shaded Conditions. J Planting Production. 2017;5(3):475-83 